\title{
The End of American Exceptionalism
}

\author{
The Social Question in the United States
}

Fred Block

Exceptionalism has been the dominant theme in United States history from its founding. At the time that the United States won its independence, the old nations against which the United States formed its identity were, in fact, the great European imperial powers-England, France, the Netherlands, and Spain, and the United States differed from these nations in critical ways. First, to expand and grow, the United States had no need to establish overseas colonies; it could draw immigrants from Europe and extend its territorial empire westward. It was able to create an internal colony in the American South where chattel slavery was the central economic institution. Second, it led the world in developing a democratic political system in which the right to vote was given to most adult white males. However, the tensions between slave states and free states resulted in the creation of a uniquely constrained central government. ${ }^{1}$ Third, the combination of early democracy, the continuing inflows of both coerced and free laborers, and the richness of the American continent created a uniquely productive economy that sustained unprecedented levels of prosperity for two full centuries. Together, these elements made the trajectory of the United States exceptional. ${ }^{2}$

But over the last forty-five years, American exceptionalism seems to have come to an end. Werner Sombart insisted that there was no socialism in America because "all socialist utopias came to nothing on roast beef and apple pie,"3 meaning that the material prosperity and upward mobility available to white workers in the United States precluded the kind of mass socialist movements that emerged in Europe. But for the last forty years, both prosperity and upward mobility have receded. Real wages in the United States have stagnated, and the number of well-paid manufacturing jobs has dropped precipitously. Moreover, rates of 
intergenerational mobility in the United States are now well below that of many countries in Europe. ${ }^{4}$

One of the key elements in this transformation has been the informalization of labor market arrangements in the United States. Through systematic efforts by employers, private-sector unionization rates have been falling for decades and now hover around 10 percent. When not represented by unions or protected by contract, employment in the United States is "at will," so that employees can be fired for any reason, no matter how arbitrary. Nevertheless, employers have sought even greater control over wage costs by increasing their use of contingent workers to fill job openings. This includes temporary workers, part-time workers, day laborers, and individuals who are defined as independent contractors, such as drivers for ridesharing services such as Uber and Lyft. By one estimate, contingent employment had risen to 40 percent of the labor force by $2010 .^{5}$

Stagnating wages and rising economic insecurity played a role in the election of Donald Trump as president in November 2016. The U.S. political system has multiple barriers to block the ascendance of populist demagogues, but Trump overcame those obstacles. His slogan “Make America Great Again” tacitly recognizes the disappearance of American exceptionalism. Yet another marker of this disappearance was the strength of support for Bernie Sanders, an avowed socialist, in the Democratic primaries in 2016.

There is, of course, a global dimension to this shift. From the end of World War II to the fall of the Soviet Union in 1989, the United States used its military and economic strength to create a coherent structure of global order built around free trade and free capital movements. ${ }^{6}$ But the ability of the United States to shape the globe has declined sharply. The failed U.S. military interventions in Afghanistan and Iraq demonstrate the limits of U.S. military power. The U.S. pressure for free capital movements and "free trade" culminated in the disastrous global financial crisis that revealed the fragility of the U.S. economic model. Moreover, global hegemony ceased to provide benefits for much of the U.S. population, as the costs of empire rose while the economic rewards were concentrated in the hands of a small oligarchic elite.

This essay will, however, focus almost exclusively on the factors internal to the United States that have brought American exceptionalism to an end. The argument is that the overly ambitious extension of U.S. power globally has simply magnified these internal dynamics. The argument is organized in three parts. The first traces the arc of American exceptionalism from the nineteenth century through to the middle of the twentieth century. The second part focuses on the causes and the consequences of the right turn in U.S. politics that began in the 1970s and 1980 s. The policy choices in that period created severe economic inequality and the deep social and political polarization that is currently reflected in the electoral arena. The final part examines the lived experience of polarization and shows how 
different social groups have responded to the crisis of American exceptionalism in sharply divergent ways.

\section{PART 1: THE REALITY OF EXCEPTIONALISM}

My argument relies on Monica Prasad's important book The Land of Too Much. ${ }^{8}$ She argues that the U.S. economy was inserted into the global economy in a way very different from Europe in the nineteenth century and that that divergence channeled state building in the United States in a unique direction. Specifically, Prasad places farmers at the center of U.S. state building, in contrast to Europe, where that role was played by the industrial working class.

Prasad begins her story in the 1870 s, but there are elements that started substantially earlier. Agriculture in the United States was far more productive than farming in Europe, and the industrial working class in the United States was weaker than comparable European working-class movements. Both of these elements connect back to key elements of American exceptionalism-the reality of slavery and its legacy, the early adoption of universal suffrage for white men, and the westward expansion of the United States, driven by the inflow of European immigrants. Strong demand for raw cotton from the slave plantations of the American South pushed the slave economy's westward expansion. The cotton trade generated great fortunes for Northern merchants, and the reinvestment of these profits fueled the economic development of the new nation. ${ }^{9}$ But the economic dynamism of the new nation was also fueled by the democratic ethos in the Northern states.

Tocqueville identified several distinct ways in which democratic and egalitarian values contributed significantly to economic vitality. ${ }^{10}$ There was a widely shared emphasis on self-improvement that led to the world's first public school system and institutions that allowed working people to improve their skills. Employees were often deeply engaged and productive at the workplace because they envisioned later setting out on their own to start a business. The importance of innovation was symbolized by the patent museum in Washington, DC, where visitors could inspect the physical models required for each patent application. This spirit was also embraced by farmers, who were eager to embrace new techniques that would improve yields and who would ultimately press for assistance from government agencies. The pattern in which the United States invested earlier than other nations in needed infrastructure, such as canals, was already well established in the early years of the Republic. This pattern was continued with Lincoln's decision to build the intercontinental rail system.

This economic dynamism allowed the United States to contest for global leadership in industrial technologies in the last part of the nineteenth century, but these legacies also shaped the peculiar development of the industrial working class in the United States. Early suffrage meant that white workers were largely incorporated into the "two-party" political system, so they were less likely to develop 
the consciousness of themselves as a separate class that was both economically exploited and politically excluded. ${ }^{11}$ Moreover, the racial privilege enjoyed by white workers relative to blacks and to multiple waves of new immigrants made the construction of working-class solidarity a more difficult task than in most European nations. Finally, the vast distances in the new nation made it far more difficult to coordinate social movements than in European nations, where populations were heavily concentrated in a few major cities.

This dynamic market economy with a politically weaker industrial working class sets the stage for Prasad's argument. The U.S. comparative advantage began in agriculture, because of rich farmland and the rapid adoption of more productive technologies, but by the 1890 s, a similar advantage existed in many sectors of manufacturing. To protect themselves from being inundated with imports from the United States, Europeans turned to tariffs and to economic policies that restricted wage increases to help them compete with the United States. In the second half of the twentieth century, Europeans would compensate for these limits on individual consumption by expanding public outlays for collective consumption, including old-age pensions and public services.

In the United States, in contrast, there was no advantage in protectionism or in restricting individual consumption. On the contrary, the model that was ultimately consolidated with the New Deal expanded the availability of credit, so that consumers would be able to purchase a growing share of the "too much" production. This direction began with radical agrarian pressures for greater availability of credit at reasonable rates that culminated in the Federal Reserve System and the Federal Farm Loan Act of 1916. The New Deal further expanded farm credit and created a national system of subsidized mortgage loans to facilitate mass home ownership. ${ }^{12}$

The last important step in Prasad's argument is that during the New Deal, agrarian interests succeeded in defeating a national sales tax. Farmers insisted that the government should rely on payroll taxes and the progressive income tax to raise revenues. New Deal social-welfare measures were created later than in Europe and were weaker because they were less universal. However, the mechanism of financing made it substantially harder to extend welfare programs in later decades because of the absence in the United States of the kind of broad-based consumption taxes that have financed welfare-state expansion in Europe. ${ }^{13}$

\section{DIVERGENCES AFTER THE NEW DEAL}

Prasad's framework helps us to understand the divergent trajectories of the United States and Europe in the years after World War II. Starting during postwar reconstruction, European countries continued to restrain the growth of wages to restore their competitiveness, but under pressure from a still powerful organized working class, they engaged in the progressive expansion of forms of collective consumption, including systems of national health insurance. This was financed through 
the expansion of consumption taxes, as big businesses saw benefits from a more educated and healthier work force. ${ }^{14}$

In the United States, in contrast, the achievement of the New Deal system of agricultural price supports was the death knell of agrarian radicalism. Without its earlier agrarian allies, organized labor's political influence and power also declined. Labor-union density reached its peak level in the mid 1950s, before a relentless decline. ${ }^{15}$ Initiatives to expand the scope of the welfare state were both more modest and more fiercely resisted than in Europe. By the 1970s, the heavy reliance of the federal government on the income tax and the payroll tax had generated a powerful opposition to increased taxation. ${ }^{16}$

Prasad also rejects the argument that the stinginess of the U.S. welfare state is a symptom of a lack of state capacity. Her view is that because of the importance of agrarian radicalism, U.S. state capacity developed on a different trajectory from Europe, with much more emphasis on building strong and independent regulatory agencies. ${ }^{17}$

U.S. government agencies were also able to nurture new industries and new technologies in much the same way that the Department of Agriculture had diffused new and more productive agricultural technologies. To be sure, this developmental side of the U.S. state was enormously enhanced by the growth of military and science spending in the Cold War era. However, starting in the 1980s, there were systematic initiatives to extend this developmental capacity beyond the Department of Defense, and these initiatives have been highly effective in maintaining the United States' superiority in technological innovation. ${ }^{18}$

\section{PART 2: WEAKENING THE U.S. MODEL}

Despite the historic weakness of the labor movement in the United States, the United States was still able to create a particularly dynamic version of a market economy, largely because of its strong democratic traditions and the opportunity to expand across a vast continent rich in natural resources. This was facilitated by continuing investments in public education and a responsive government that developed capacities to invest in infrastructure, regulatory, and developmental policies that gave the United States global technological leadership.

Finally, the democratic legacy opened the way for powerful social movements that have periodically been able to overcome the entrenched power of reactionary interests whose reign threatened further economic advances. Abolitionism and the Civil Right Movement of the 1950s and 1960s fit here, as does the agrarian radicalism that Prasad emphasizes. ${ }^{19}$

But politics in the United States took a right turn in the mid-1970s that has weakened the democratic character of the society and has fundamentally jeopardized the country's economic dynamism. ${ }^{20}$ Piketty has highlighted the most important consequence of this right turn: the dramatic increase in income and 
wealth inequality that began in the early 1980 s and has continued ever since. ${ }^{21}$ From 1981, the first year of the Reagan Administration, to 2014, the share of household income going to the top 1 percent of households is estimated to have increased from 8 percent to 18 percent.

The explanation for this right turn is closely linked to the turbulent Vietnam decade, from escalation of the war in August of 1964 to Nixon's presidential resignation in August of 1974 .

Faced by a powerful communist insurgency in South Vietnam, U.S. policy makers were unable to recognize the limits of U.S. military power. The obvious futility of the U.S. effort produced a sustained crisis in the United States, with the emergence of powerful left-wing social movements. There was an unprecedented public debate about the United States' global role, and there was a dramatic decline in public confidence in the political elites of both major parties.

Big business firms in the United States responded to the domestic turmoil of the Vietnam era and the failure of two presidents by reconsidering their political stance. Many previously centrist business leaders began to build an alliance with the right wing of the Republican Party, based on free-market economics and the call to roll back taxation, regulation, and labor-union gains.

At the grassroots, the turmoil of the Vietnam decade also produced significant popular backlash against the movements of the 196os. Both in the South and in the North, many white voters were pushed to the right by escalating militancy among African Americans. Similarly, there was a strong backlash against the emergence of second-wave feminism, particularly after the Supreme Court legalized abortion in 1973. Moreover, the antiauthoritarian politics of the student movement fueled a revival of traditional values and increased mobilization among evangelical Christians. Finally, resistance to higher levels of taxation allowed all of these currents to fuse together into the strongest right-wing coalition that the nation had seen since the 1920 .

This convergence between grassroots conservatism and a turn to the right by big business led to Ronald Reagan's election as president in 1980. Reagan then set in motion a series of policies that helped generate the shifts in income and wealth inequality that Piketty has documented. The massive "supply-side" tax cuts carried out in 1981 significantly reduced the tax burden on high-income households and increased the returns to speculation in financial markets. Reagan also implemented a shift in antitrust policy that conformed to the anti-regulatory ideology of Milton Friedman's Chicago school of economics. ${ }^{22}$ A huge increase in executive compensation followed, generally implemented through stock options and stock grants, which was justified by the ideology of shareholder value. In the same vein, the Reagan administration encouraged the consolidation of the banking sector and accelerated the financialization of the economy. ${ }^{23}$

Reagan fired the government employees who worked in the air traffic control system who went on strike in 1981. This sent a powerful signal, since most other 
working people could be replaced far more easily. Employers took advantage by forcing unionized employees to make wage concessions and increasing the use of contingent workers. Reagan also made significant cuts in spending in a range of government programs designed to aid the poor and eliminated the revenuesharing program that had eased the fiscal strain on cities. ${ }^{24}$

Most of these Reagan-era policies were continued and intensified all the way up to the Wall Street meltdown in the fall of 2008. Subsequent administrations tilted taxes even further in favor of the rich and continued to encourage the rapid expansion of the financial sector. The Clinton administration was friendlier to unions and expanded a program that provided additional income to low-wage workers. However, the Clinton efforts did not halt the trend toward greater inequality.

From 1945 to 1975 , the federal government had provided state and local governments with considerable support to build and repair infrastructure. This support eased the fiscal pressure on these units and facilitated increased funding of public education, including higher education. But from the 1980 os onward, fiscal pressures on state and local governments intensified. Politicians became extremely reluctant to push tax increases. The end of revenue sharing and other federal cutbacks meant that states and localities had to cover a substantially larger share of infrastructure outlays at a time when such projects were rising in cost. Finally, the "war on crime," which dramatically increased incarceration rates, particularly for minority men, meant that the costs of the prison and criminal-justice systems were adding additional strain to state and local budgets. ${ }^{25}$

State and local governments also cut back a variety of services that had previously provided assistance to poorer households. The most dramatic impact has been the consequence for expenditures on public higher education. In the first thirty years after World War II, public colleges and universities were often tuitionfree or had nominal fees that did not represent a burden for enrollees. But as a result of ongoing budgetary pressures, more and more of the cost of public higher education now falls on the students. ${ }^{26}$ Large sectors of the population are effectively priced out of the market for higher education, and many college graduates are weighted down with tens of thousands of dollars of educational debt.

This represents a reversal of one of the longstanding patterns of American exceptionalism-greater investments in increased educational attainment than other nations. U.S. educational leadership came to an abrupt end in the last quarter of the twentieth century. ${ }^{27}$ Other nations surged ahead of the United States with ever-larger shares of their young people directed to higher education or sophisticated apprenticeship programs. The reading, writing, and math skills of adults in Scandinavia are now substantially higher than those in the United States. This, in turn, puts U.S.-based firms at a competitive disadvantage as they try to compete in global markets.

It is still the case that large investments by the U.S. government in science and technology have given the United States an advantage in the development 
of cutting-edge technologies. Specifically, the U.S. global leadership in developing the internet and computer technologies has allowed firms such as Microsoft, Apple, Google, and Facebook to earn fabulous profits from their global operations. But this sectoral success has also served to mask deeper problems with the U.S. economic model.

\section{CONSEQUENCES OF THE RIGHT TURN}

Theorists of the free market insisted that policies of the right turn - such as cutting taxes, removing burdensome regulations on business, and shrinking the size of civilian government operations-would operate like a magical elixir and revitalize the U.S. economy. But the consequences of these policies have been exactly the opposite; they have undermined the historic sources of vitality in the U.S. economy.

The right turn accelerated the concentration of wealth and income in the hands of the top 1 percent. Middle-income and poor households responded to constrained income growth by taking on greater debt, and this was a major contributor to the mortgage meltdown in 2007 and $2008 .{ }^{28}$ The concentration of income at the top also intensifies speculative activity, since those with vast fortunes have strong motivation to put excess funds into more risky investments that promise a higher return. At the same time, the ideology that corporations should be managed to maximize shareholder value has justified the shifts in corporate compensation that have allowed top managers to pocket a growing share of corporate profits. ${ }^{29}$ The major corporations have accumulated huge cash hordes, but their investment outlays remain anemic. Finally, the concentration of income and wealth at the top, as we shall see, is a major contributor to de-democratization, as the very rich use a small share of their resources to tilt tax and regulatory policies in their own favor. ${ }^{30}$

The largest firms in different sectors of the economy have become entrenched, so they can avoid competition and extract unjustified rents. This is most extreme with the largest financial institutions, those that were encouraged from the Reagan administration onward to grow ever larger. And even after the government rescue, the surviving firms continue to control a more substantial share of consumer deposits.

Big pharmaceutical companies have developed few effective new medications in their own laboratories, but they have been able to leverage their ability to finance clinical trials and their access to physicians, so that smaller firms need to work with them to get their innovations to the market. ${ }^{31}$ Similarly, the giant technology firms are able to use their vast portfolios of patents to intimidate wouldbe competitors from challenging their entrenched positions. They are also able simply to buy out potential competitors who are in the early stages of developing a competing technology, since such startups face such difficulties obtaining the finances to remain independent. 
One of the keys to this process of entrenchment has been the relaxation of antitrust enforcement that began during the Reagan administration. ${ }^{32}$ Corporate practices that in an earlier period might have precipitated vigorous antitrust actions were seen by the Justice Department and the courts as harmless. Economic dynamism is diminished, because many entrenched firms have too many weapons in their arsenal to blunt competitive challenges.

De-democratization goes along with entrenchment and enrichment. ${ }^{33}$ Democratic practices in the United States have long been flawed, because elections are run by partisan local officials, numerous barriers to broad electoral participation were erected in the early decades of the twentieth century, and expensive electoral campaigns have given rich donors disproportionate influence. However, since the right turn, a series of court decisions have further weakened the voice of the people. A decades-long conservative campaign to reverse the protections provided by the Voting Rights Act culminated in a Supreme Court decision in 2013 that gave local jurisdictions much greater leeway to discriminate against minority voters.

Most importantly, the conservative majority on the Supreme Court has repeatedly held that campaign donations are equivalent to speech, so that efforts to limit the impact of big money on campaigns violates the constitution. With this logic, the court has opened the floodgates of donations by the rich and corporations and gutted regulations that were intended, at least, to force the disclosure of such contributions.

De-democratization makes the political system unresponsive to reform demands. For example, it is widely recognized that the current tax system, in which multimillionaires routinely pay taxes at a lower rate than their rank-andfile employees, is grossly unfair. However, strategic campaign contributions assure that key congressional leaders will be able to block reform legislation from coming to the floor.

The combined consequences of enrichment, entrenchment, and de-democratization has been a stagnant economy, characterized by insufficient demand and diminishing opportunities for upward mobility. Aggregate demand has been weakened by the tilting of income toward the rich, by all levels of government facing ongoing fiscal crises, and by the reluctance of wealthy corporations to invest in new projects. At the same time, for the last generation, the combination of foreign competition and technological advances have dramatically reduced manufacturing employment, significantly weakened new job creation, and have pushed a growing share of the labor force into poorly paid jobs in services and retail trade.

The impact is indicated by studies showing elevated death rates in the United States in 2014 as compared to 1999 among white men between ages of forty-five and fifty-four with only a high school education. ${ }^{34}$ This finding goes against the general trend of declining death rates for people in midlife, and the apparent reason for the uptick is suicides and deaths related to drug and alcohol abuse. The 
finding is limited to white men; Hispanics and African Americans in that age group continue to show declining death rates. The logical explanation is that while Hispanics and African Americans continue to face difficult labor-market conditions, racial barriers have diminished over the last generation. But white men, who historically enjoyed an advantaged position in the labor market, face both worsening conditions and an erosion of their historic privileges.

While this represents just one piece of data, it highlights the end of American exceptionalism. The same population group-prime-age working-class white men-that through much of U.S. history did not rally to the banners of radical movements, are now experiencing increasingly difficult circumstances. Some of them are dying at a higher rate, and others are, in fact, rallying behind the banners of outsider political figures such as Donald Trump and Bernie Sanders.

\section{PART 3: THE LIVED EXPERIENCE OF POLARIZATION}

For many social scientists, it is almost a reflex to think in terms of class and jump to the conclusion that people who are in similar structural positions should respond in similar ways to economic hardship. But the reality of American exceptionalism is that class position has always been mediated through other identities, such as ethnicity, religion, generation, and region, in shaping political behavior. Different population groups have responded to parallel economic shocks with extremely divergent forms of political responses. Here, the U.S. pattern looks similar to that of Europe, where economic shocks have significantly weakened centrist political parties and have strengthened the oppositional parties of the right and the left.

The best way to conceptualize the economic dislocations is in terms of what Jacob Hacker has called, the "great risk shift." 35 Basically, the transformations in the United States since the right turn of the 1980s have significantly increased the volatility of family income. Hacker shows that by 2002, basically one household in six, headed by a prime-age adult, was likely to experience a 50 percent or greater income drop from one year to the next, and more recent analyses have shown that this volatility has continued to rise.

The most important cause is the increasing amount of turnover in the labor market. Informalization means fewer people enjoy job security. Total employment at large corporations in the United States has been falling sharply for decades, and a greater share of those that they employ work on a contingent basis. ${ }^{36}$ Ongoing fiscal pressures have produced comparable changes for public-sector employees, who have also become increasingly vulnerable to layoffs. An ever-larger share of the labor force works at small- and medium-sized firms that are very exposed to ups and downs of the business cycle.

The second key cause is the weakening of the safety net that is supposed to protect households from this kind of volatility. Over the decades, the share of those facing unemployment who qualify for benefits has been falling; it is now at less 
than a quarter of all those counted as unemployed. Moreover, even for those lucky enough to receive benefits, the ratio of those benefits to the lost wages has also been falling. At the same time, a variety of state and local programs that provided cash assistance have been phased out, and the national program that was designed to protect children from poverty was effectively gutted by legislation passed in 1996. ${ }^{37}$ Furthermore, the dramatic increases in health care costs and the spottiness of safety-net programs means that families can also be driven into poverty by either the uncompensated costs or the lost income precipitated by a severe health crisis.

In fact, the largest single cause of personal bankruptcy in the United States remains costs associated with a medical crisis. For a large portion of the U.S. population, when a doctor's visit detects a serious illness, it raises both the threat of mortality and the possibility of financial ruin. The Affordable Care Act ameliorated this problem by providing health insurance to many families that previously could not afford coverage. But families remain at risk of impoverishment caused by a health crisis. A study released in early 2016 reported that 37 percent of respondents living in households with earnings below $\$ 50,000$ experienced difficulties paying medical bills..$^{38}$ This is one of the reasons why Republican attacks on the Affordable Care Act had some political traction; the law has not alleviated the public's economic anxieties about health costs.

These two primary factors, in turn, set in motion two secondary processes. The first is family breakup. Households that are strained by income instability are at greater risk of dissolution, which often means a significant income loss for some members of the original household. Second, economic stresses, including loss of income or sustained fears of an imminent loss of income, often produce anxiety, depression, and loss of self-esteem. This, in turn, can result in alcohol or drug abuse, as individuals self-medicate to manage their symptoms. However, drug or alcohol dependence can lead to arrest, job losses, and further shocks to household income.

Households in the United States have sought to protect themselves from incomes that are volatile or insufficient through increased resort to borrowing. However, this expedient frequently backfires, leaving households facing even greater economic uncertainty. During the long increase in housing prices from the 1990 s through 2007, many households increased their mortgage debt. When house prices stopped rising, millions of households owed more on their mortgages than the houses were worth. The defaulted loans and foreclosures that continued for years meant that many formerly middle-class households lost whatever saving they had been able to accumulate. ${ }^{39}$

There has also been a vast increase in student debt over the last decade. The problem has been particularly egregious for students attending for-profit institutions, where instruction was supposed to lead to job opportunities, which failed to materialize. But as the job market has worsened in the post-2008 period, many 
students who attended legitimate colleges and universities have found themselves unable to find employment while they still carry loan burdens of $\$ 100,000$ to $\$ 200,000$. Since student debt is difficult to discharge with personal bankruptcy, it becomes a durable burden that individuals carry for years. ${ }^{40}$ Recent reports have indicated that thousands of elderly people have portions of their social security checks withheld, because even as they reach retirement, they still owe payments on student debt. ${ }^{41}$

\section{DIVERGENT RESPONSES}

\section{Those at the Bottom}

Ethnographic accounts have illuminated the misery of those living at the bottom of U.S. society. ${ }^{42}$ Edin and Shaefer document the lives of people living on $\$ 2.00$ a day or less. ${ }^{43}$ The stories are basically similar-a family is surviving on the basis of a paycheck from a low-wage job, but a conflict with a boss or a health crisis or an arrest leads to the loss of the job and a downward spiral that includes spells of living with relatives or living on the streets. Welfare is not an option either because they do not know it exists or because they are unlikely to be deemed eligible, despite desperate circumstances. Similar stories have been told by Desmond, documenting the moment at which families are put out on the street because the landlord has decided that they are no longer acceptable as tenants. ${ }^{44}$

But both these households that are in extreme poverty and many of those who are a single paycheck away from extreme poverty are unlikely to have any political response to their economic marginalization. Just getting by, just surviving is a fulltime job, and they are unlikely to vote. Low-income households that are vulnerable to evictions or frequent change of residence are unlikely to have updated their residence information to remain eligible.

In fact, in many parts of the country, there is no longer an entity or organization that seeks to connect poor people to the political process. This role was filled for decades by labor unions, which played a role in getting their members and their members' neighbors registered to vote. But as unions have declined or disappeared in many communities, no other organizations are available to fill the vacuum. Exit polls from 2016 showed that households of all ethnicities with income below $\$ 50,000$ voted for Clinton over Trump by about ten points, while most other income groups were close to evenly split. However, voters in the bottom quintile have turnout rates of about 55 percent in presidential elections, while those in the top quintile reach 80 percent turnout. ${ }^{45}$

\section{Working-Class Minorities}

There are many African American and Latino households who live one or two rungs up the social ladder from those living in poverty or at daily risk of poverty. Members of this group face continuing insecurity in the labor market, many of 
them were victimized by subprime mortgage lending, and they disproportionately face displacement, as gentrification drives them out of urban neighborhoods that have become attractive to higher-income households. Members of this group have particularly high anxieties about the prospects for their children. On the one side, repeated episodes of police violence have exposed the vulnerability of minority youths and young adults. On the other, poor schools and financial barriers to higher education create significant barriers to upward mobility.

However, men in this demographic group do not face the higher levels of mortality reported for working-class white men. The usual explanation is that minority men have long faced racial barriers and discrimination in the labor market, so they do not confront growing instability in labor markets as something new and surprising. But it might also be that a recent history of political mobilization within these communities provides an alternative to despair and self-medication.

In fact, there has been a resurgence of political engagement in these communities. Movements such as Black Lives Matter, the Fight for Fifteen-to raise the minimum wage-and campaigns for an end to deportations and a path to citizenship within immigrant communities are indicators of the potential for broader political mobilization..$^{46}$ But as we saw in the 1960 , such claims making within minority communities generates an instant backlash, provoking political figures such as Donald Trump to double down on anti-immigrant and pro-police rhetoric.

\section{Whites without College Degrees}

Here is where one sees the most divergent responses to greater economic insecurity. Depending largely upon the specific communities where they live, people in this demographic group rallied behind the very different candidacies of Donald Trump and Bernie Sanders. In a number of Northern states, Sanders won big victories over Clinton in white working-class communities. However, in the November election, non-college-educated whites favored Trump over Clinton by close to a 70 to 30 margin..$^{47}$ But this figure has to be adjusted for the regional reality that whites without a college education in the South tend to vote Republican by even larger margins. For example, white evangelical voters, many of whom live in the South and do not have college degrees, voted for Trump over Clinton by 81 percent over 16 percent.

What seems indisputable is that a slice of non-college-educated whites in midwestern heartland states, such as Wisconsin, Iowa, Ohio, Michigan, and Pennsylvania, who had been part of the Obama coalition in 2008 and 2012, crossed over and supported Trump in 2016, and that shift in those five states accounted for Trump's narrow Electoral College victory. The actual number of people who made this shift was not particularly large; it could have been as few as half a million voters, since Trump's margin in some of these states was small. However, this was enough to make the difference, given that other parts of the Obama coalition-African 
Americans and young people-did not turn out to the polls for Clinton as strongly as they had for Obama.

These non-college-educated switchers in the industrial heartland had presumably voted for Obama because of his promise of significant change, but they are still hurting, and they probably voted for Trump because of his promise to bring back manufacturing jobs. For these and many other voters, Clinton was seen as an unattractive establishment figure who was unlikely to pursue a bold and disruptive agenda.

To be sure, a much larger portion of Trump's total vote came from those noncollege-educated whites who had rallied to the Tea Party political insurgency that first emerged in 2009. Well-funded national right-wing organizations such as Americans for Prosperity played a key role in turning grassroots activism into a national political force. However, the movement has a very real popular base among whites, particularly in the South and in rural communities and small towns across the nation. Arlie Hochschild has explained the "deep story" of Tea Party activists with the metaphor of people patiently standing on a line stretching for miles toward a horizon of opportunity and success, but suddenly others start cutting in to the line, including minorities, immigrants, and even endangered species..$^{4}$ This story resonates both with those who have achieved some level of economic security, as well as those who are struggling to keep their heads above water.

Two of the core issues for Tea Party activists featured prominently in the rhetoric of Donald Trump. Tea Party activists were particularly mobilized by both the economic and cultural threat of immigration; they did not want immigrants coming into the United States, taking jobs and speaking other languages. Also, the iconic Tea Party slogan was "Keep your government hands off my Medicare." Activists wanted to protect their own entitlement to Medicare and Social Security while urging political leaders to cut back spending on the undeserving. ${ }^{49}$ Trump's campaign was unusual for the Republican Party in his strong stance against cuts to both Social Security and Medicare, since the party's orthodoxy has been that the entitlement programs need dramatic retrenchment.

Some voters in this group chose Trump; and others, Sanders, because voters go with the version of economic populism that makes sense to them, given their locality and their voting history. For many voters, partisan identification is deeply held and often inherited from their parents. But what happened in places like Wisconsin, Michigan, and Ohio is that some unionized workers rejected the advice of their own unions and cast a protest vote in favor of Trump. The irony is that in all of these states, strongly anti-union Republican governors had pursued aggressive policies since 2011 to weaken trade unions. In short, these voters risked a vote for Trump knowing that the unions had been too weak to fight back successfully against the right. ${ }^{50}$ 


\section{Whites with College Degrees}

Within this demographic group, the key dividing line appears to be age. Historically, a college degree made a significant difference for labor-market outcomes, and those with such degrees experienced lower unemployment rates and a significant wage premium. The consequence was that whites with a college education have slightly favored the Republicans in recent elections. However, the same cannot be said for younger college graduates. Those who have entered the labor market over the last decade faced either a massive recession or a weak recovery. Even when jobs are available, employers often prefer to increase the number of temporary or precarious workers, who can easily be fired in the event of another economic downturn. Older employees are less likely to move on or retire, given the uncertain economic environment. Finally, many industries are facing disruptive changes that create additional pressure on employers to limit the number of relatively secure positions.

The combination of a difficult labor market and the heavy burden of student debt have pushed many young college-educated whites leftward..$^{11}$ This was a big factor in the Sanders campaign. However, the ultimate impact of this political shift remains uncertain, because young people are substantially less likely than their elders to participate in elections and some older college-educated white voters, who had been enthusiastic members of the Obama electorate, have grown disillusioned with the Democrats in recent years.

\section{CONCLUSION}

The right turn in U.S. politics that began in the 1980s has effectively dismantled some of the key structures of American exceptionalism, especially the confidence that individual initiative and hard work are sufficient to achieve upward mobility. The consequence has been growing ideological polarization, political stalemate, and the rise of new political currents, such as populist authoritarianism and socialism, that were previously restricted to the margins of politics in the United States. But this analysis also suggests that the future direction of the United States is extremely difficult to predict, since it is dependent on the complex interaction among leadership personalities, the political choices made by diverse population groups, and global events.

To be sure, the likeliest possibility remains a continuation of the status quo, with polarization and stalemate growing even worse. Since the U.S. constitution provides multiple veto points, the election of Donald Trump will likely result in continuing stalemate between Congress and the president, with few significant legislative changes. Ironically, the new administration's only significant legislative achievement-the massive tax-cut bill that was successfully pushed through in late 2017-will further intensify wealth and income inequalities, contributing to 
greater economic instability and rising public anger and discontent. But intensifying polarization and growing popular dissatisfaction cannot go on indefinitely. Sooner or later, the pressure for a break will become overwhelming, but that still leaves two distinct and radically different trajectories.

The first is an extended episode of authoritarian governance as domestic turbulence and perceived foreign threats are used as a pretext for suspending the constitution and giving the executive branch broad powers to impose new policies. Such a turn would probably coincide with a new hot or cold war against one or another foreign enemy or an escalation of ongoing fighting in the Middle East or Afghanistan. In both the recent and distant past, the need to defeat foreign enemies has been used as the justification for such departures from constitutional government as the internment of the Japanese during World War II, anti-communist witch hunts in the 1950s, or the use of torture against suspected terrorists after 9/11. A new authoritarianism is likely to use similar tactics.

The second possibility is another epoch of reform, comparable to the New Deal, in which a reform administration, pressed by powerful social movements, pursues an aggressive project of redistributing income and revitalizing the U.S. economy. Suggestions of this possibility lie in the broad resistance to the Trump administration that began with the huge women's marches that took place the day after Trump's inauguration in 2017 and again a year later. The Trump administration has simultaneously mounted frontal attacks on immigrants and immigrant-rights supporters, labor unions, African Americans, Latinos, Asian Americans, advocates for the environment and environmental justice, the women's movement, advocates for prison and criminal-justice reform, gun-control groups, proponents of marijuana decriminalization, defenders of an open internet, advocates for public schools, supporters of transgender rights, opponents of unlimited corporate power, and those fighting to reduce shocking inequalities of wealth and income inequality. These broad and indiscriminate attacks provide organizers with the opportunity to fuse these diverse constituencies into a powerful and majoritarian reform coalition.

However, historically even the most powerful resistance movements have found it difficult to maintain unity once they have driven their opponents from power. Moreover, in the United States, there are few signs thus far that Trump's many opponents have coalesced around a coherent reform agenda. But it is also possible that the seriousness of the threat posed by Trump's authoritarian impulses could produce a surprising level of cooperation between centrist Democratic politicians and social-movement activists.

Whether the United States moves toward authoritarianism or a new reform epoch will depend ultimately on both events internal to the United States and on what goes on in the rest of the world. Increased global disorder and mounting threats of war could strengthen anti-democratic forces. On the other hand, 
successful reform initiatives in other parts of the world to strengthen democratic governance while reducing inequality and environmental degradation could inspire similar efforts in the United States.

\section{NOTES}

1. Gary Gerstle, Liberty and Coercion (Princeton, NJ: Princeton University Press, 2015).

2. To be sure, all national trajectories are exceptional; there is no typical path. The point is that exceptionalism has loomed larger in ideology and popular consciousness in the United States than in most other places.

3. Werner Sombart, Why Is There No Socialism in the United States? trans. Patricia M. Hocking and C. T. Husbands (White Plains, NY: International Arts and Sciences Press, 1976), 106.

4. Timothy Smeeding, Robert Erikson, and Markus Jäntti, eds. Persistence, Privilege, and Parenting: The Comparative Study of Intergenerational Mobility (New York: Russell Sage Foundation, 2011).

5. U.S. Government Accountability Office, "Contingent Workforce: Size, Characteristics, Earnings and Benefits," 4.

6. Fred Block, The Origins of International Economic Disorder (Berkeley: University of California Press, 1977).

7. Leo Panitch and Sam Gindin, The Making of Global Capitalism (New York: Verso, 2012).

8. Monica Prasad, The Land of Too Much (Cambridge, MA: Harvard University Press, 2012 ).

9. Sven Beckert, Empire of Cotton (New York: Knopf, 2014).

10. Alexis de Tocqueville, Democracy in America, 2 vols., trans. Henry Reeve (New York: Vintage, 1945).

11. Ira Katznelson and Aristide Zolberg, eds. Working Class Formation: Nineteenth-Century Patterns in Europe and the United States (Princeton, NJ: Princeton University Press, 1986).

12. Gerstle, Liberty and Coercion, also emphasizes the importance of the agrarian roots of the New Deal.

13. Peter Lindert, Growing Public (New York: Cambridge University Press, 2004).

14. Fred Block and Margaret Somers, The Power of Market Fundamentalism (Cambridge, MA: Harvard University Press, 2014), chap. 7.

15. Thomas Kochan, Harry Katz, and Robert McKersie, The Transformation of American Industrial Relations (Ithaca, NY: Cornell University Press, 1986).

16. Isaac Martin, The Permanent Tax Revolt (Stanford, CA: Stanford University Press, 2008); and Isaac Martin, Rich People's Movements (New York: Oxford, 2013).

17. Gerald Berk, Louis Brandeis and the Making of Regulated Competition (New York: Cambridge University Press, 2009).

18. Fred Block, "Swimming against the Current: The Rise of a Hidden Developmental State in the United States" Politics and Society 36, no. 2 (2008): 169-206; Fred Block, "Innovation and the Invisible Hand of Government," in State of Innovation, ed. Fred Block and Matthew R. Keller, 1-26 (Boulder, CO: Paradigm, 2011); and Mariana Mazzucato, The Entrepreneurial State (London: Anthem, 2013).

19. Frances Fox Piven, Challenging Authority (Lanham, MD: Rowman and Littlefield, 2006).

20. The term was initially used as a title by Thomas Ferguson and Joel Rogers, Right Turn (New York: Hill \& Wang, 1986). This argument is developed at greater length in Block, Capitalism: The Future of an Illusion (Oakland: University of California Press, 2018).

21. Thomas Piketty, Capital in the 21st Century, trans. Arthur Goldhammer (Cambridge, MA: Harvard University Press, 2014).

22. Brett Christophers, The Great Leveler: Capitalism and Competition in the Court of Law (Cambridge, MA: Harvard University Press, 2016). 
23. Gerald Davis, Managed by the Markets (New York: Oxford University Press, 2009); and Greta Krippner, Capitalizing on Crisis (Cambridge, MA: Harvard University Press, 2012).

24. Many of these shifts are well documented in Jacob Hacker and Paul Pierson, Off Center: The Republican Revolution and the Erosion of American Democracy (New Haven, CT: Yale University Press, 2006).

25. Michelle Alexander, The New Jim Crow (New York: New Press, 2011).

26. Christopher Newfield, Unmaking the Public University (Cambridge, MA: Harvard University Press, 2011).

27. Claudia Goldin and Lawrence F. Katz, The Race between Education and Technology. (Cambridge, MA: Belknap Press, 2008),

28. Kurtulus Gemici, "Beyond the Minsky and Polanyi Moments: Social Origins of the Foreclosure Crisis," Politics and Society 44, no. 1 (2016): 15-43.

29. William Lazonick, Sustaining Prosperity in the New Economy? (Kalamazoo, MI: Upjohn, 2009.

30. A number of analysts have referred to a process of de-democratization, but Colin Crouch, PostDemocracy (Cambridge: Polity, 2004), was among the earliest.

31. Ann Case and Angus Deaton, "Rising Morbidity and Mortality in Midlife among White NonHispanic Americans in the 21st Century," Proceedings of the National Academy of Sciences (December 8, 2015): 15078-83.

32. Christophers, The Great Leveler.

33. Jeffrey Winters, Oligarchy (New York: Cambridge University Press, 2011).

34. Case and Deaton, "Rising Morbidity and Mortality."

35. Jacob Hacker, The Great Risk Shift (New York: Oxford University Press, 2006).

36. Davis, Managed by the Markets.

37. Jane L. Collins and Victoria Mayer, Both Hands Tied: Welfare Reform and the Race to the Bottom in the Low-Wage Labor Market (Chicago: University of Chicago Press, 2010).

38. Liz Hamel et al., The Burden of Medical Debt (Kaiser Family Foundation, January 2016).

39. Gemici, "Beyond the Minsky and Polanyi Moments."

40. Charlie Eaton, Jacob Habinek, Adam Goldstein, and Cyrus Dioun, "The Financialization of U.S. Higher Education," Socio-Economic Review 14, no. 3 (2016): 507-35.

41. Danny Vinik, "The Latest Victims of Student Debt? The Elderly," Politico, February 25, 2016, www.politico.com/agenda/story/2016/o2/the-latest-victims-of-student-debt-the-elderly-000053.

42. Still relevant is William Julius Wilson, When Work Disappears (New York: Knopf, 1996).

43. Kathryn J. Edin and H. Luke Shaefer, \$2.oo a Day (Boston: Houghton Mifflin Harcourt, 2015).

44. Matthew Desmond, Evicted (New York: Crown, 2016).

45. Jan Leighley and Jonathan Nagler, Who Votes Now? (Princeton, NJ: Princeton University Press, 2013), chap. 2.

46. Sarah Jaffe, Necessary Trouble (New York: Nation Books, 2016).

47. Data are from exit polls as reported in K. K. Rebecca Lai et al. "How the Presidential Election Took a U-Turn in 2016," New York Times, November 10, 2016.

48. Arlie Hochschild, Strangers in Their Own Land (New York: New Press, 2016).

49. Lawrence Rosenthal and Christine Trost, eds., Steep: The Precipitous Rise of the Tea Party. (Berkeley: University of California Press, 2012).

50. For a useful account of the unsuccessful Wisconsin mobilization to protect union rights, see Jane L. Collins, The Politics of Value: Three Movements to Change How We Think about the Economy (Chicago: University of Chicago Press, 2017).

51. Sarah Jaffe, Necessary Trouble (New York: Nation Books, 2016). 